\title{
Clothing Retail Channel Use and Digital Behavior: Generation
}

\section{and Gender Differences}

\author{
Pauline Sullivan $^{1^{*}} \&$ Sae-Young J. Hyun ${ }^{2}$ \\ ${ }^{1}$ Associate Professor, Department of Family and Consumer Sciences, Tennessee State University, \\ Nashville, TN, USA \\ ${ }^{2}$ Honors Student, Farragut High School, Knoxville, TN, USA \\ ${ }^{*}$ Pauline Sullivan, E-mail: psulliva@tnstate.edu
}

\begin{abstract}
This study examined whether selecting certain retail channels to purchase clothing reflects generational and gender preferences as well as their digital behavior. Based on 1000 consumer cases from a Cornell National Social Survey conducted in 2012, this study employed correspondence analysis to segment clothing retail channel groups and relate the segments to generational cohorts and gender. Overall, the majority of Gen Y, Gen X, and Baby Boomer male consumers preferred the store-only channel, while the majority of female consumers of these generations liked the digital-only or digital-store channel for purchasing clothing. On the other hand, both male and female seniors liked catalogs (either digital-catalog or catalog only) for purchasing clothing. In addition, ANOVA was run with generation and gender as the independent variables and digital behaviors as the dependent variables. Results provided strategic information on how to target each clothing channel segment using the digital behavior of different generations and gender.
\end{abstract}

Keywords

clothing retail channel, digital behavior, correspondence analysis, generation, gender

\section{Introduction}

As retail and technology evolve, consumers can choose to purchase apparel through a greater variety of retail channels than before; from innovative off-line pop-up stores, traditional retail outlets and direct marketing, to online or mobile formats (Hansen \& Jensen 2009; Strang, 2013). While multiple channel options are available, electronic shopping's share of total retail sales increases at a faster rate than that of traditional offline retail channels. In 2013, the average online clothing purchase was approximately $22 \%$ more than average online purchases in other product categories (Jackson, 2015), Multiple channel options provide more opportunities to retailers as well as consumers. For instance, both off-line and online retail channels rely on smart phones for retail traffic, generated by consumers' comparison shopping or product information searches. Berthiaume (2015) reported the number of online shopping carts created increased 26\% (2014-2015), as 15\% of shoppers added items to their cart through smart phones. In addition, off-line shopping is affected by consumers' digital behavior because consumers have easy access to online coupons and information on special promotions or sales. In fact, an increasing number of brick-and-mortar retailers use online coupons and promotion codes to reach their digitally-oriented consumers. McGuinness (2015) reports that digital channels influenced 64\% of 2015 brick and mortar sales. One reason is that $76 \%$ of consumers had an online interaction with a brand in brick-and-mortar stores prior to a purchase. As such, retail channels are more integrated than before, because they impact how consumers search for information and purchase. Whether a single retail channel or multichannel retailer, understanding consumers' digital behavior is important for marketers 
when developing strategies to reach their target market.

The literature associates generation (Bigne, Ruiz, \& Sanz, 2005; Colucci \& Scarpi, 2013; Lian \& Yen, 2014) and gender (Ha \& Stoel, 2004; Seock \& Bailey, 2008) with consumers' use of technology and retail channels. For instance, Generation X (Gen X hereafter) adopts new technology at a slower rate than Generation Y (Gen Y hereafter), but faster than Baby Boomers (Taylor \& Gao, 2014). In contrast, Gen Y female consumers use the internet more than Gen Y males when searching for information about clothing products (Ha \& Stoel, 2004). Additionally, older consumers prefer shopping via traditional stores or catalogs, while younger consumers prefer shopping online. Thus, exploration of gender and generational differences in digital behavior is essential when developing targeted marketing strategies to consumers who use a particular retail channel or channels.

The purpose of this study is two-fold. First, it will identify clothing retail channel segments based on preferred channels for purchasing clothing, generational cohorts and gender. Second, it will analyze generational cohort and gender digital behavior information to effectively reach each clothing retail channel segment.

\section{Clothing Retail Channels}

Consumers can purchase via one retail channel or across channels. About $66 \%$ of shoppers use more than one channel for shopping and 33\% use two or more channels (The Verde Group, 2011). Multi-channel clothing shoppers may initially search for information at online stores and then shop at a brick-and-mortar store, or vice versa (Melis, Campo, Breugelmans, \& Lamey, 2015). Thus multi-channel retailing has evolved into omni-channel retailing, in which online and offline channels are integrated to provide consumers with seamless shopping experiences. Hence, channel integration has been acknowledged as a promising strategy for retailers. Herhausen, Binder, Schögel and Herrmann (2015) find that online-offline channel integration associated with consumers' shopping behavior, including product search, intention to buy, and willingness-to-pay differed by product category. In the product category of flip flops, willingness-to-pay increased $28 \%$ when online and offline channels were integrated, while it increased 35\% for sunglasses. Results from this study suggest the channel integration yields a larger increase (22\%) in willingness-to-pay in the online channel than in the offline channel (7\%). Yet, Herhausen et al. (2015) argue that strategies for successful channel integration in creating positive customer reactions toward different channels remain unclear.

Goldsmith and Flynn (2005) provide insights specific to clothing buying retail channel use. Their study finds positive relationships in clothing purchases among all three retail channels. However, the association for online and catalog channel is stronger, when compared to online and brick-and-mortar channels. Similarly, purchases are greater when consumers shop via a combination of brick-and-mortar with catalog channels, rather than the combination of brick-and-mortar with online channels. In addition, Cunningham (2015) reveals online shoppers have favorable intentions towards buying the same brand in a brick-and-mortar store. However, the literature reveals a dearth of information about clothing channel selection and digital behavior.

In sum, consumers shop for clothing across retail channels of brick-and-mortar stores, digital stores, and catalogs. This study will identify clothing retail channel segments based on preferred channels when buying clothing, generational cohorts and gender. In order to target specific clothing channel segments, marketers must understand consumers' digital behavior related to the usage of mobile phones, social networking, and Facebook friends. This digital consumer behavior differs by generation and gender. 


\section{Generational Differences in Clothing Channel Use and Digital Behavior}

Cohort analysis examines the effect of age group, controlling for social and structural differences, on consumers' opinion and changes in their beliefs or behavior. This type of analysis is useful in market segmentation because each cohort shares values, attitudes, consumption patterns, or an ability to use technology (Holt, 1997; Parment, 2013). Therefore, it can be postulated that members in the same generation cohort share similar digital behavior patterns and use of retail channels when purchasing clothing.

\subsection{Generation $Y$}

Members of Gen Y were born between 1981 and 1996 (Reeve \& Oh, 2007). They are the largest group of consumers and have a profound influence on clothing sales (Fry, 2015). Gen Y consumers are technologically proficient, regular users of social media, and early adopters of new products (Ordun, 2015). Therefore, Gen $Y$ consumers are more likely to use interactive media platforms than are Gen $X$ or Baby Boomers. They use an assortment of devices, tablets, cell phones, texting, and instant messaging of technological connectivity to connect with people and retail outlets. As a result, social media friends and the virtual world influence Gen Y's buying decisions. Also, Gen Y is more likely to use online coupons than are Gen X and Baby Boomers (Moore, 2012). Furthermore, Gen Y consumers shop online for product information, and often buy items without tangibly examining the product prior to purchase (Ordun, 2015). Gen Y's use of online information search leads to efficient shopping decisions because they scrutinize internet offers prior to purchase, make decisions quickly, and expect fast transactions (Harris, Stiles, \& Durocher, 2011).

When shopping in brick-and-mortar stores, Gen Y consumers do not perceive in-store interactions with a salesperson as necessary, yet they expect a fast purchase as well as visual communication that is timely and reliable (Harris et al., 2011). Not surprisingly, Gen Y consumers desire less human interaction in the shopping experience.

\subsection{Generation $X$}

The generational cohort, Gen X, includes those who are born between 1965 and 1980 (Reeve \& Oh, 2007). This in-between generation is smaller than both Gen Y and Baby Boomers. With little free time left due to their busy careers, Gen $X$ values convenience and prefers one-stop shopping. Findings about Gen X's use of internet for social networking are somewhat conflicting. According to Moore (2012), Gen $\mathrm{X}$ is less likely to access social networks via mobile phones or social media blogs than Gen Y, but more likely to purchase online (Philip, 2015). On the other hand, Williams and Page (2011) report Gen $\mathrm{X}$ is less likely to socially interact on the web than Gen $\mathrm{Y}$ but uses the internet as an information resource, for email, and as entertainment. Dias (2003) suggests that advertising targeted to Gen X should use a traditional media mix including online and offline marketing vehicles.

\subsection{Baby Boomers}

Baby Boomers were born between 1946 and 1964 (Reeve \& Oh, 2007). The number of Baby Boomers peaked in 1999, but has decreased since then and their number will continue to decline. Boomers make rational consumption decisions and their decisions are influenced by experts and close friends. Also Baby Boomers are direct when shopping; they know what they intend to purchase and plan their shopping trip (Hughes, 2008).

Prior to the 1990s, Boomers preferred shopping in malls when they were younger. By the 1990s, they wanted one-stop shopping in brick-and-stores to accommodate their time constraints (Martin, 2009). However, these consumers increasingly recognize the Internet as a place for shopping (Hughs, 2008). A study by Eastman and Iyer (2004) indicates about $46 \%$ of Baby Boomers use the internet a minimum 
of 10 hours per week. The primary reasons Boomers use the internet are: to connect with friends and family (66\%), read the news online (about 37\%), and shopping (35\%). According to Leppel and McCloskey (2011), internet use varies according to the age group category. Consumers between the ages of 50 and 69 outspend and buy more frequently online compared to those age 70 and over, as well as shoppers between the ages of 18 and 25. About $60 \%$ of Baby Boomers receive emails from retailers and $85 \%$ purchase as a result of communications (Leppel \& McCloskey, 2011). However, older Baby Boomers are less likely to download apps on their mobile phones than other generations (Moore, 2012).

\subsection{Seniors}

Seniors (also called "mature consumers") were born before 1946 (Reeve \& Oh, 2007). According to Moschis, Ferguson and Zhu (2011), these consumers prefer department stores for shopping because of easy product returns and receiving refunds. About $78 \%$ of Seniors view easy return and refunds relevant to their decision to patronize a department store. Other factors influencing their patronage decisions, in order of importance, are sales (66.7\%), ease of locating merchandise (60.5\%), availability of personnel who could assist them (59.5\%), and an assortment of familiar brands/items (58.2\%). In addition, half of senior customers value stores located near other places they visit. Also, Seniors want comfort and socializing when shopping. Price reductions or specials influence almost $80 \%$ of senior consumers' purchase decision for clothing and footwear brands.

Older adults' adoption of new retail technologies has lagged behind younger generations (Barnard, Bradley, Hodsgon, \& Lloyd, 2013), maybe because they do not have the same level of interest in and exposure to new technologies (Vroman, Arthanat, \& Lysack, 2015). However, older consumers increasingly use retail technologies for information search and making purchases. For instance, Leppel and McCloskey (2011) discover that, although a majority of senior consumers prefer shop in brick-and-mortar stores or via catalogs, they use the internet for information searches and purchasing more than before. They report that a growing number of consumers over the age of 70 seek information about products and services on the internet. Furthermore, Karimi and Neustaedter (2011) report senior consumers increasingly use social media (e.g., Facebook) as a means of communication.

\section{Gender Differences in Clothing Channel Use and Digital Behavior}

Gender is a significant factor in understanding consumer behavior because males and females are subjected to different social roles and pressures (Fisher \& Arnold, 1994). Holbrook (1986) claims that females are more visually oriented and intrinsically motivated than males are. According to Campbell (1997), males and females have different attitudes toward shopping. Women are more positive about shopping than men, while men shop to fulfill an instrumental need, rather than "shopping for shopping's sake". Hu and Jasper (2004) support this argument as they find that men are typically impulsive, utilitarian shoppers while women are planned, hedonic shoppers. Relatedly, several studies find male shoppers prefer fast and efficient shopping, when compared to female shoppers (Hart, Farrell, Stachow, Reed, \& Cadogan, 2007; Herter, Pizzutti dos Santos, \& Costa Pinto, 2014).

Given that the literature above discusses gender differences in the way consumers shop, it is reasonable to expect females and males behave differently in their digital behavior and when selecting retail channels for clothing shopping. For example, Rodgers and Harris (2003) argue males are dominant e-commerce shoppers. They find women have less favorable perceptions of Internet shopping than males. Males trust the internet more and have higher online satisfaction levels than females. Similarly, Garbarino and Strahilevitz (2004) reveal that women perceive a high level of risk from online 
purchasing. Chiu, Lin and Tang (2005) find male consumers are less likely than females to select an online channel for purchasing, yet they have a significantly higher score for perceived ease of online shopping.

With respect to clothing, females have a greater need, than do males, to touch all apparel products before purchasing (Cho \& Workman, 2011). A study by Moschis et al. (2011) reveals older females, compared to older males, want to easily locate merchandise, when shopping at a department store. Their study also finds that older females consider billing and payment options more often than older males in channel selection. Among Gen Y consumers, females use the internet more than males when searching for information about apparel products (Ha \& Stoel, 2004). Chiger (2001) also notes that female consumers are more likely to buy clothing, jewelry, and home furnishings online. According to Valentine and Powers (2013), Gen Y females' clothing purchases are approximately 33\% higher than all other generations, while Gen Y males buy 50\% more apparel than all other generations.

The Verde Group (2011) identifies four types of multi-channel shoppers: "tech savvy-multi-channel shopper", "retail loyalist, multi-channel shopper", "discerning online shopper", and "experiential brick and mortar shopper". The "retail loyalist, multi-channel shopper" typically is male, whereas the "experiential brick and mortar shopper" typically is female. However, Cho and Workman (2011) find gender does not significantly influence multi-channel retail selection. Given this conflicting information, this study will examine whether gender is an important factor influencing clothing channel selection and digital behavior.

\section{Method}

\subsection{Data}

Data used in the study were obtained from 1000 completed cases in the Cornell National Social Survey, conducted by Survey Research Institute at Cornell University in 2012 (www.sri.cornell.edu). This public-use data file was created by the Cornell Institute for Social and Economic Research (CISER). The survey sample, provided by Marketing Systems Group, is a Random Digit Dial (RDD) list drawn from the continental United States and includes cell phones. The survey was conducted using a Computer Assisted Telephone Interviewing (CATI) software system. Among the respondents, 32.7\% were male and $67.3 \%$ were female; $56.8 \%$ were married. The largest number $(26.2 \%)$ of the respondents had household income of $\$ 50,000-\$ 75,000$, followed by $\$ 40,000-\$ 50,000(13.2 \%)$ and $\$ 75,000-\$ 100,000(13.0 \%)$. In terms of education, the largest number $(29.4 \%)$ were college graduate, followed by some college or 2-year college degree (24.3\%) and post graduate degree (19.7\%). A total of $65 \%$ of the respondents used the web for more than four years. The majority of respondents $(69.2 \%)$ were between 25 and 50 years of age, with the median age of 48 (Cornell National Social Survey, 2012). For grouping generations, the respondents were divided into four generations: Generation $Y$ (born between 1981 and 1996), Generation X (born between 1965 and 1980), Baby Boomers (born between 1946 and 1964), and Seniors (born before 1946) (Reeve \& Oh, 2007).

\subsection{Correspondence Analysis}

Correspondence Analysis (CA) is a multivariate perceptual mapping technique that identifies relationships among the variable categories and objects (i.e., cases) by using a graphical representation (Hair, Black, Babin, \& Anderson, 2009). In correspondence analysis, mapping variables in a two-dimensional space allows researchers to simply find dependencies among variables, thereby providing information on segmenting and interpreting consumer groups (Greenacre \& Hastie, 1987; Herrmann \& Huber, 2000). In this study, correspondence analysis was employed to segment clothing 
channel groups based on brick-and-mortar stores, digital channels and catalogs, which were matched with generational cohorts and gender.

Correspondence analysis can be used in conjunction with other methods by providing statistical precision in assessment (Atilgan, Akinci, \& Aksoy, 2003). Therefore, univariate analyses of variance (ANOVAs) were used to supplement the results of correspondence analysis of clothing channels by generation and gender. ANOVA results provide strategic information on how to target each clothing channel segment by examining digital behavior according to generational cohorts and gender. All analyses were conducted using PROC GLM in SAS University Edition.

\subsection{Clothing Channel Groups}

Clothing channel groups were identified by two questions. The first question was "Do you use a computer with internet or any mobile device (like a smart phone or tablet PC) to make clothing purchases)?" The answer was coded as Y (yes) or N (no). The second question was "Given the choice between purchasing clothing using a computer with internet, a mobile device, a mail/phone-order catalog, or by going to a store, which would you prefer?". The two answers of "Prefer computer with internet" and "Prefer mobile device" were grouped into "Digital channel" coded as " $d$ ". "Prefer mail/phone-order catalog" was coded as "c" and "Prefer going to store" was coded as "s". Therefore, there were five groups of clothing channels: Yd (digital-only), Ys (digital-store), Yc (digital-catalog), Ns (store-only), and Nc (catalog-only). Table 1 illustrates the frequencies of these five clothing channel groups by generation and gender.

Table 1. Groups by Clothing Channel

\begin{tabular}{llllllll}
\hline Generation & Gender & Nc & Ns & Yc & Yd & Ys & Total $^{*}$ \\
\hline 1 & 1 & 0 & 55 & 0 & 9 & 48 & 112 \\
1 & 2 & 0 & 31 & 0 & 23 & 46 & 100 \\
2 & 1 & 0 & 58 & 0 & 16 & 44 & 118 \\
2 & 2 & 0 & 39 & 2 & 21 & 53 & 115 \\
3 & 1 & 2 & 98 & 0 & 22 & 48 & 170 \\
3 & 2 & 4 & 75 & 3 & 35 & 81 & 198 \\
4 & 1 & 1 & 47 & 1 & 2 & 12 & 63 \\
4 & 2 & 5 & 52 & 2 & 6 & 14 & 79 \\
\hline
\end{tabular}

Note. Generation: $1=$ Generation Y, $2=$ Generation X, $3=$ Baby Boomers, $4=$ Seniors; $\quad$ Gender: $1=$ Male, 2 = Female.

Nc (Catalog-only); Ns (Store-only); Yc (Digital-Catalog); Yd (Digital-only); Ys (Digital-Store).

${ }^{*}$ Total percentage may not equal $100 \%$ due to no response.

The clothing channel groups were mapped in CA to assess how each group was correlated with generation and gender. Figure 1 shows the position of each consumer group and clothing channel in the correspondence space. Figure 1 exhibits two dimensions (horizontal and vertical) accounting for 92.59\% of the total variance (the first dimension, $72.33 \%$; the second dimension, 20.26\%), indicating that the horizontal spread (first dimension) of the points captures the most essential information in comparing the relationships among variables.

Using the correspondence analysis map (see Figure 1), three segments emerged: (a) store-only (Ns), (b) digital (digital-only, Yd and digital-store, Ys), and (c) catalog (catalog-only, Nc and digital-catalog, Yc). Male Generation Y, X and Baby Boomers were tightly grouped with the store-only channel (Ns). 
Female Generation Y, X and Baby Boomers were grouped with both digital-only (Yd) and digital-store channel (Ys). Female and male Senior consumers were, to a lesser extent, tied to digital-catalog (Yc) and catalog-only channel (Nc). In summary, three segments were identified: (a) the "store-only channel" preferred by male consumers of Gen Y, Gen X, and Baby Boomers, (b) the "digital-only or digital-store channel" preferred by female consumers of Gen Y, Gen X and Baby Boomers; and (c) the “digital-catalog or catalog-only channel” preferred by Seniors, whether male or female.

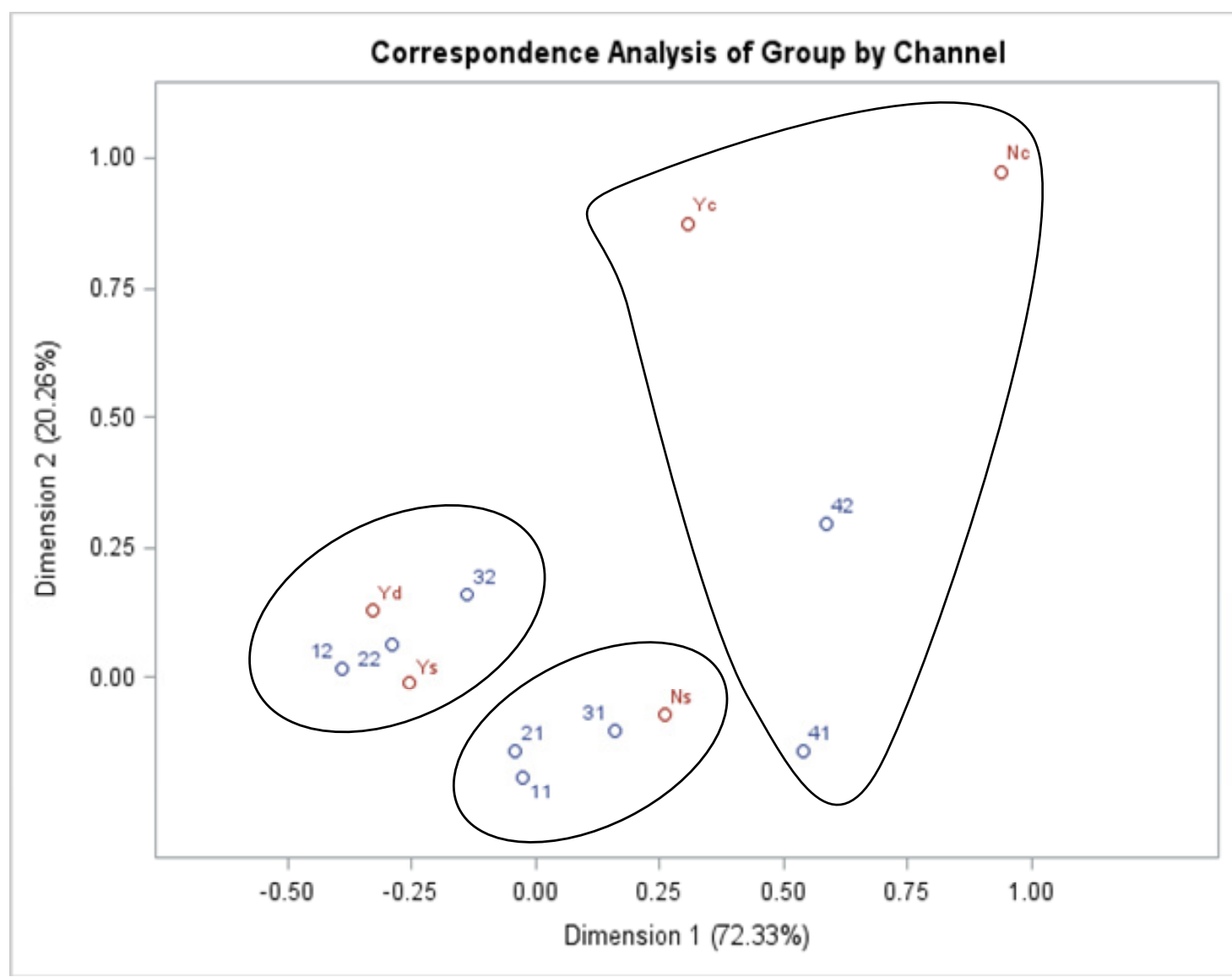

Figure 1. Correspondence Analysis

Note. Ns: Store-only, Yd: Digital-only, Ys: Digital-Store, Nc: Catalog-only, Yc: Digital-Catalog.

Two numbers represent generation and gender (e.g., 12 = Generation Y female).

\subsection{Strategies for Clothing Channel Segments}

In order to assess the effects of gender and generation on digital behavior, we employed ANOVAs. The independent variables were gender and generation. The dependent digital behavior variables were: "Wake up with phone", "Sleep with phone", "Social networking with others", "Social networking for self", and "Facebook friends". These five dependent items are reported in Table 2.

Table 2. Measures of Digital Behavior

\begin{tabular}{lll}
\hline Variable & Statement & $\begin{array}{l}\text { Response } \\
\text { Categories }\end{array}$ \\
\hline Wake up with phone & & How soon after you wake up do you check your phone (excluding using it \\
& as an alarm clock)? & minutes \\
\hline
\end{tabular}




\begin{tabular}{|c|c|c|}
\hline & & $\begin{array}{l}2=6-30 \\
\text { minutes }\end{array}$ \\
\hline & & $3=31-60$ \\
\hline & & minutes \\
\hline & & $4=$ After 60 \\
\hline & & minutes \\
\hline \multirow[t]{5}{*}{ Sleep with phone } & How often do you sleep with your phone in your bed or bring it into your & $1=$ never \\
\hline & bed during the night? & $2=$ rarely \\
\hline & & $3=$ sometimes \\
\hline & & $4=$ often \\
\hline & & 5 = always \\
\hline \multirow{6}{*}{$\begin{array}{l}\text { Social } \\
\text { networking-Others }\end{array}$} & Do you ever use a social networking site like Facebook, Google+, or & $1=$ never \\
\hline & MySpace to check information about others? & $2=$ rarely \\
\hline & & $3=$ sometimes \\
\hline & & $4=$ often \\
\hline & & $5=$ all the \\
\hline & & time \\
\hline \multirow{6}{*}{$\begin{array}{l}\text { Social } \\
\text { networking-Self }\end{array}$} & Do you ever use a social networking site like Facebook, Google+, or & $1=$ never \\
\hline & MySpace to share information about yourself? & $2=$ rarely \\
\hline & & $3=$ sometimes \\
\hline & & $4=$ often \\
\hline & & $5=$ all the \\
\hline & & time \\
\hline Facebook friends & $\begin{array}{l}\text { Thinking just about your personal Facebook profile (excluding any } \\
\text { business or other non-personal Facebook pages), approximately how } \\
\text { many total Facebook friends do you have? }\end{array}$ & \\
\hline
\end{tabular}

${ }^{*}$ Values are recoded for analyses.

Prior to running ANOVAs, we examined the descriptive statistics of digital behavior based on generations and gender. Table 3 illustrates Means (M) and Standard Deviations (SD) of five digital behavior variables that result from each level of two independent variables. Not surprisingly, the means of all five digital behavior variables decreased as a generation gets older. However, gender differences did not show consistent patterns among the five variables.

Table 3. Means of Digital Behavior by Generation and Gender

\begin{tabular}{|c|c|c|c|c|c|c|c|c|c|c|c|c|}
\hline \multirow[t]{2}{*}{${ }^{1} \mathrm{Gr}$} & \multirow[t]{2}{*}{${ }^{2} \mathrm{Gd}$} & \multirow[t]{2}{*}{$\mathrm{N}^{*}$} & \multirow{2}{*}{$\begin{array}{l}\text { Wake } \\
\text { phone } \\
M\end{array}$} & \multirow{2}{*}{$\begin{array}{l}\text { up with } \\
\text { SD }\end{array}$} & \multirow{2}{*}{$\begin{array}{l}\text { Sleep } \\
\text { phone } \\
M\end{array}$} & with & \multicolumn{2}{|c|}{$\begin{array}{l}\text { Social } \\
\text { networking- } \\
\text { Others }\end{array}$} & \multicolumn{2}{|c|}{$\begin{array}{l}\text { Social } \\
\text { networking- } \\
\text { Self }\end{array}$} & \multicolumn{2}{|c|}{$\begin{array}{l}\text { Facebook } \\
\text { friends }\end{array}$} \\
\hline & & & & & & $S D$ & $M$ & $S D$ & $M$ & $S D$ & $M$ & $S D$ \\
\hline 1 & 1 & 87 & 3.03 & 1.13 & 3.49 & 1.75 & 3.67 & 1.02 & 3.07 & 1.31 & 500 & 652 \\
\hline 1 & 2 & 90 & 3.32 & 0.99 & 3.49 & 1.70 & 4.06 & 1.08 & 3.47 & 1.16 & 513 & 460 \\
\hline
\end{tabular}




\begin{tabular}{lllllllllllll}
\hline 2 & 1 & 66 & 2.74 & 1.17 & 2.58 & 1.75 & 3.32 & 1.13 & 2.73 & 1.10 & 371 & 753 \\
2 & 2 & 81 & 3.00 & 1.17 & 3.22 & 1.84 & 3.67 & 1.16 & 3.17 & 1.24 & 281 & 321 \\
3 & 1 & 54 & 2.83 & 1.26 & 2.80 & 1.89 & 2.93 & 1.24 & 2.52 & 1.18 & 115 & 141 \\
3 & 2 & 121 & 1.88 & 1.13 & 2.16 & 1.70 & 3.44 & 1.09 & 2.65 & 1.09 & 123 & 119 \\
4 & 1 & 11 & 2.27 & 1.19 & 2.45 & 1.75 & 2.36 & 1.03 & 2.09 & 0.70 & 67 & 102 \\
4 & 2 & 25 & 1.16 & 0.47 & 1.24 & 0.83 & 3.36 & 1.25 & 2.08 & 0.86 & 60 & 85 \\
\hline
\end{tabular}

Note. ${ }^{1}$ Generation: $1=$ Generation Y, $2=$ Generation X, 3 = Baby Boomers, $4=$ Seniors; ${ }^{2}$ Gender: $1=$ Male, 2 = Female.

${ }^{*}$ Total percentage may not equal $100 \%$ due to missing values.

Specifically, ANOVA results provide significant differences in all five digital behavior variables among generations, while significant differences existed in only two variables (i.e., "wake up with phone" and "social network-others") between males and females (Table 4). With respect to generations, Gen Y consumers were most active in digital behavior; they most frequently wake up and sleep with their mobile phone, social networking for others as well as for themselves, and have the largest number of Facebook friends. These frequencies and numbers were sequentially followed by Gen X, Baby Boomers and Seniors. In terms of gender, male consumers were more likely to wake up with phone, while female consumers were more likely to social network with others.

Table 4. ANOVA: Comparing Means of Digital Behavior by Generation and Gender

\begin{tabular}{|c|c|c|c|c|c|c|c|}
\hline & Group & $\mathrm{N}^{*}$ & Wake up with phone & Sleep with phone & $\begin{array}{l}\text { Social } \\
\text { networking- } \\
\text { Others }\end{array}$ & $\begin{array}{l}\text { Social } \\
\text { networking- } \\
\text { Self }\end{array}$ & $\begin{array}{l}\text { Facebook } \\
\text { friends }\end{array}$ \\
\hline \multirow[t]{5}{*}{ Generation } & 1 & 177 & 3.18 & 3.49 & 3.87 & 3.27 & 507 \\
\hline & 2 & 147 & 2.87 & 2.90 & 3.50 & 2.95 & 326 \\
\hline & 3 & 175 & 2.36 & 2.48 & 3.19 & 2.59 & 119 \\
\hline & 4 & 36 & 1.72 & 1.85 & 2.86 & 2.09 & 64 \\
\hline & \multicolumn{2}{|c|}{ F-statistic } & $24.32^{* * *}$ & $13.64^{* * *}$ & $13.50^{* * *}$ & $14.71^{* * *}$ & $24.00^{* * *}$ \\
\hline \multirow[t]{3}{*}{ Gender } & 1 & 218 & 2.72 & 2.83 & 3.07 & 2.60 & 263 \\
\hline & 2 & 317 & 2.34 & 2.53 & 3.63 & 2.84 & 244 \\
\hline & \multicolumn{2}{|c|}{ F-statistic } & $8.96^{* *}$ & 2.37 & $19.44^{* * *}$ & 3.35 & 0.14 \\
\hline
\end{tabular}

Note. ${ }^{* *} p<.01,{ }^{* * *} p<.001$.

Generation: $1=$ Generation Y, 2 = Generation X, 3 = Baby Boomers, 4 = Seniors.

Gender: $1=$ Male, $2=$ Female.

* Total percentage may not equal $100 \%$ due to missing values.

\section{Discussion and Implications}

This study found three clothing retail channel segments (i.e., "store-only", "store-only ordigital-store", and "catalog-only or digital-catalog" channels) that are tied to gender and generational cohorts. Overall, 
the majority of male consumers among Gen Y, Gen X and Baby Boomers preferred a brick-and-mortar store for purchasing clothing. This finding contradicts the findings of Rodgers and Harris (2003) and The Verde Group (2011), but somewhat supports the finding of Chiu et al. (2005). The majority of female consumers preferred a digital-only or digital-store channel for purchasing clothing. On the other hand, both male and female Seniors preferred catalogs (either digital-catalog or catalog only) for purchasing clothing. It is apparent that channel integration provides an opportunity to better target older consumers as well as younger consumers, whether they use a single channel or multiple channels to buy clothing. This result reinforces the importance of understanding digital behavior for all generational cohorts as well as gender to provide strategic implications to target each clothing retail channel segment. Implications for each clothing retail channel segment are provided below based on digital behavior of specific group of generational cohorts and gender that constitute each clothing retail channel segment.

First, the "store-only channel" segment consists of Gen Y, Gen X and baby boomer males. These consumers check their mobile phone when they wake up and sleep with it. Specifically, Gen Y male consumers are most connected to their mobile phones and use them as the most preferred way of getting information. These results have definite implications for future mobile strategies for business practitioners. For instance, retailers aiming to cater to Gen Y male consumers may benefit from providing mobile friendly websites and mobile apps that can boost mobile search visibility. They can develop their brand pages based on social networking sites or use App notifications to engage conversations with Gen Y male consumers. These avenues allow consumers to be more personally involved with the brand and efficiently find the information that they want, thereby influencing their purchase in a brick-and-mortar store.

Gen X males sleep and wake up with their mobile phone, to a lesser extent than Gen Y. The finding that Gen $\mathrm{X}$ ranks second in connectivity and social networking may be due to less familiarity with technology or more time constraints than Gen Y. However, the data indicate social networking such as Facebook may provide the best means of reaching these consumers. Therefore, retailers should use social networking sites such as Facebook, for example, to match clothing items and create looks for Gen X male consumers to reduce their time for shopping among different items.

Baby boomer males also sleep and wake up with their mobile phone. However, they do so to a lesser extent than Gen Y and Gen X. The potential to reach them via mobile phones has not been realized, compared to younger generations. While scores for social networking are lower than those of younger generations, social networking scores are higher than for wake up and sleep with phone. Therefore, social networking appears to be the best option to reach male Boomers. Brick-and-mortar stores need to have social networking sites that reflect the lifestyle of this group such as enjoying the empty nester stage, demanding good customer service, and buying name brands or luxurious brands (Trocchia, Saine, \& Luckett, 2015).

In terms of gender differences, males have a significantly higher score in wake up with phone, which indicates they check their phone much earlier in the day than females. Therefore, retailers should consider releasing product or shopping information on their website at different times depending on gender. Retailers can analyze male consumers' shopping profile to increase the probability that they would be interested in limited time in-store promotions or sales. Retail brands can notify Gen Y male consumers about their time sales or online exclusive offers on their Instagram pages that contain attractive visual image of products. As a long-term goal, retailers should explore the time their male consumers get the message online and the sales revenue to determine specific time that generates the 
most return on investment.

The "digital-only or digital-store channel" segment consists of Gen Y, Gen X and Baby Boomer females. Overall, females scored significantly higher than males in the use of social networking for others. In the current market where word-of-mouth via electronic is more important than ever (Feng \& Papatla, 2014), this finding is important to retailers because they can communicate product information to their consumers and show endorsements by those who have purchased these products. For both Gen $\mathrm{Y}$ and Gen $\mathrm{X}$ female consumers, social networking for others and for themselves and Facebook seem the best means to reach these consumers. Interactivity between retailers and these consumers can be the key in reaching these consumers. For instance, the brand's website could host a brand community where Gen Y and Gen X females can post their sensory evaluation (e.g., touch and feel) and pictures of how they use the brand's clothing in a look, and allow the feedback from other users. This is important especially to female consumers because they have a greater need to touch and feel products before purchasing than male consumers (Cho \& Workman, 2011). Moreover, retailers can leverage various social networking platforms such as Facebook, Google + and MySpace to communicate with consumers. Though the best practice to approach these consumers seems to be using Facebook, managing multiple social networking accounts can offer considerable resources and communities where consumers can review, research, co-create and share information about the brands they consume (Sashi, 2012). Although Baby Boomers scored lowest in digital behavior among consumers in this segment, social networking for others seems to the most promising means of reaching this group. Therefore, brick-and-mortar retailers should not ignore providing product information and ratings online to this group.

The "digital-catalog or catalog-only channel" segment is composed of male and female Seniors. Seniors scored lowest in all digital behavior variables, which supports the finding of Barnard et al. (2013). However, the current trend shows that an increasing number of Seniors use digital media to obtain information about shopping and make purchase decisions (Vroman et al., 2015). Thus, clothing retailers targeting Seniors need to maintain digital media communications to motivate consumer purchases. Particularly, when delivering their brand messages, retailers need to tailor their messages in a clear, concise and visually appealing way so that Seniors can easily understand the values of products. This segment also uses the catalog-only channel. Therefore, catalog retailers should emphasize Senior consumers' lifestyle preferences. One way is to organize high quality products by lifestyle. For instance, golf clothing, comfortable shoes, and cruise wear can target affluent and active retirees. To increase these sales, catalog retailers can send out online newsletters that are designed to appeal to this generation, for example, focusing on comfort, friendly service, and social interaction opportunities.

Some limitations from this study can be addressed to provide suggestions for future research. The secondary data used in the study contained items that were already collected in 2012 beyond the researchers' control. In future research, a research model can be designed with primary data containing more constructs that reflect current consumer trends and can be used to accomplish the research goal. In particular, digital behavior construct items can be developed through a qualitative study by conducting a focus group interview and can be refined through a quantitative study. The current study classified consumers that use both a computer and a mobile phone into one clothing channel group. However, as new technologies constantly emerge, it would be interesting to classify different digital devices (e.g., mobile phones, computers, tablets) as separate channels. Finally, channel choices can vary depending on type of clothing. For instance, more standardized outfits such as jeans and shirts may be easily ordered online without perceiving a risk, while dress and suits may require trying on for 
a perfect fit in a brick-and-mortar store. Therefore, future studies can use specific clothing categories (e.g., social clothes, street clothes) in identifying different clothing channels.

\section{References}

Atilgan, E., Akinci, S., \& Aksoy, S. (2003). Mapping service quality in the tourism industry. Managing Service Quality, 13(5), 412-422.

Barnard, Y., Bradley, M. D., Hodsgon, F., \& Lloyd, A. D. (2013). Learning to use new technologies by older adults: Perceived difficulties, experimentation behavior and usability. Computers in Human Behavior, 29, 1715-1724.

Berthiaume, D. (2015, September 14). Study: Smartphones key to online shopping, Chain Store Age. Retrieved September 29, 2015, from http://www.chainstoreage.com/article/study-smartphonescommunity.com/digital-marketing/the-somewhat-perfect-harmony-digital-commerce-and-brick-an d-mortar-stores-01324100\#wZ3QTMmgDJi83Kuy.99

Bigne, E., Ruiz, C., \& Sanz, S. (2005). The impact of internet user shopping patterns and demographics on consumer mobile buying behaviour. Journal of Electronic Commerce Research, 6(3), 193-209.

Campbell, C. (1997). Shopping, pleasure, and the sex war. In P. Falk, \& C. Campbell (Eds.), The Shopping Experience (pp. 166-175). London: Sage.

Chiger, S. (2001). Consumer shopping survey: Part 2. Catalog Age, 18, 47-51.

Chiu, U., Lin, C., \& Tang, L. (2005). Gender differs: Assessing a model of online purchase intentions in e-tail service. Journal of Fashion Marketing and Management, 16, 416-435.

Cho, S., \& Workman, J. (2011). Gender, fashion innovativeness and opinion leadership, and need for touch: Effects on multi-channel choice and touch/non-touch preference in clothing shopping. Journal of Fashion Marketing and Management: An International Journal, 15(3), 363-382.

Colucci, M., \& Scarpi, D. (2013). Generation Y: Evidences from the fast-fashion market and implications for targeting. Journal of Business Theory and Practice, 1(1), 1-7.

Cornell National Social Survey. (2012). Survey Research Institute, Cornell Institute for Social and Economic Research.

Cunningham, N. (2015). Consumer perceptions of shopping channel attributes and risk factors influencing apparel purchases. Doctoral dissertation, University of Johannesburg.

Dias, J. P. (2003). Generational buying motivations for fashion. Journal of Fashion Marketing and Management: An International Journal, 7(1), 78-86.

Eastman, J. K., \& Iyer, R. (2004). The elderly's uses and attitudes towards the Internet. Journal of Consumer Marketing, 21(3), 208-220.

Feng, J., \& Papatla, P. (2014). Why Consumers Talk: An Investigation of the Extrinsic Motivators of Electronic Word of Mouth. Journal of Business Theory and Practice, 2(1), 63-83.

Fisher, E., \& Arnold, S. J. (1994). Sex, gender identity, gender role attitudes, and consumer behavior. Psychology and Marketing, 12(2), 163-182.

Fry, Richard. (2015). This year, millennials will overtake Baby Boomers. FacTank, Pew Research Institute.

Retrieved

from http://www.pewresearch.org/fact-tank/2015/01/16/this-year-millennials-will-o

Garbarino, E., \& Strahilevitz, M. (2004). Gender differences in the perceived risk of buying online and the effects of receiving a site recommendation. Journal of Business Research, 57, 768-775. 
Goldsmith, R. E., \& Flynn, L. R. (2005). Bricks, clicks, and pix: Apparel buyers' use of stores, internet and catalogs compared. International Journal of Retail and Distribution Management, 33(4), 271-283.

Greenacre, M., \& Hastie, T. (1987). The geometric interpretation of correspondence analysis. Journal of the American Statistical Association, 82(5), 437-447.

Ha, Y., \& Stoel, L. (2004). Internet apparel shopping behaviors: The influence of general innovativeness. International Journal of Retail \& Distribution Management, 32(8), 377-385.

Hair, J. F., Black, W. C., Babin, B. J., \& Anderson, R. E. (2009). Multivariate data analysis (7th ed.). New York, NY: Pearson Prentice Hall.

Hansen, T., \& Jensen, M. J. (2009). Shopping orientation and online clothing purchases: The role of gender and purchase situation. European Journal of Marketing, 43(9/10), 1154-1170.

Harris, K. J., Stiles, J., \& Durocher, J. (2011). A preliminary evaluation of the millennial shopping experience: Preferences and plateaus. Hospitality Review, 29(1), 2.

Hart, C., Farrell, A. M., Stachow, G., Reed, G., \& Cadogan, J. W. (2007). Enjoyment of the shopping experience: Impact on customers' repatronage intentions and gender influence. The Service Industries Journal, 27(5), 583-604.

Herhausen, D., Binder, J., Schögel, M., \& Herrmann, A. (2015). Integrating bricks with clicks: Retailer-level and channel-level outcomes of online-Offline channel integration. Journal of Retailing, 91(2), 309-325.

Herrmann, A., \& Huber, F. (2000). Value-oriented brand positioning. The International Review of Retail, Distribution and Consumer Research, 10(1), 95-112.

Herter, M. M., Pizzutti dos Santos, C., \& Pinto, D. C. (2014). Man, I shop like a woman! The effects of gender and emotions on consumer shopping behaviour outcomes. International Journal of Retail and Distribution Management, 42(9), 780-804.

Holbrook, M. B. (1986). Aims, concepts, and methods for the representation of individual differences in esthetic responses to design features. Journal of Consumer Research, 13, 337-347.

Holt, D. B. (1997). Poststructuralist lifestyle analysis: Conceptualizing the social patterning of consumption in postmodernity. Journal of Consumer research, 24, 326-350.

Hu, H., \& Jasper, C. R. (2004). Men and women: A comparison of shopping mall behavior. Journal of Shopping Center Research, 11(1), 113-131.

Hughes, A. (2008). Y and how: Strategies for reaching the elusive Generation Y consumer (p. 74). Honors College Theses,

Jackson, E. (2015, April 23). What online apparel shoppers want, Internet Retailer. Retrieved September 20, 2015, from https://www.internetretailer.com/commentary/2015/04/23/what-onlin e-ap

Karimi, A., \& Neustaedter, C. (2011). My grandma uses facebook: Communication practices of older adults in an age of social media. School of Interactive Arts \& Technology, Simon Fraser University, Surrey, BC, Canada.

Leppel, K., \& McCloskey, D. W. (2011). A cross-generational examination of electronic commerce adoption. Journal of Consumer Marketing, 28(4), 261-268.

Lian, J. W., \& Yen, D. C. (2014). Online shopping drivers and barriers for older adults: Age and gender differences. Computers in Human Behavior, 37, 133-143.

Martin, C. A. (2009). Consumption motivation and perceptions of malls: A comparison of mothers and daughters. Journal of Marketing Theory and Practice, 17(1), 49-61. 
McGuinness, A. (2015, September 16). The (Somewhat) perfect harmony: Digital commerce and brick and mortar stores. Business 2 Community. Retrieved September 20, 2015, from http://www.business2

Melis, K., Campo, K., Breugelmans, E., \& Lamey, L. (2015). The impact of the multi-channel retail mix on online store choice: Does online experience matter? Journal of Retailing, 91(2), 272-288.

mericas-neglected-middle-child

Moore, M. (2012). Interactive media usage among millennial consumers. Journal of Consumer Marketing, 29(6), 436-444.

Moschis, G. P., Ferguson, J. L., \& Zhu, M. (2011). Mature consumers' selection of apparel and footwear brands and department stores. International Journal of Retail \& Distribution Management, 39(10), 785-801.

Ordun, G. (2015). Millennial (Gen Y) Consumer Behavior Their Shopping Preferences and Perceptual Maps Associated With Brand Loyalty. Canadian Social Science, 11(4), 40-55.

Parment, A. (2013). Generation Y vs. Baby Boomers: Shopping behavior, buyer involvement and implications for retailing. Journal of Retailing and Consumer Services, 20(2), 189-191.

Philip, B. (2015). Generation X marks the spot. Canadian Business, 88(6), 22.

Reeves, T. C., \& Oh, E. J. (2007). Generation differences and educational technology research. In J. M. Spector, M. D. Merrill, J. J. G. van Merriënboer, \& M. Driscoll (Eds.), Handbook of research on educational communications and technology (pp. 295-303). Mahwah, NJ: Lawrence Erlbaum Associates.

Rodgers, S., \& Harris, M. A. (2003). Gender and e-commerce: An exploratory study. Journal of advertising research, 43(3), 322-329.

Sashi, C. M. (2012). Customer engagement, buyer-seller relationships, and social media. Management Decision, 50(2), 253-272.

Seock, Y. K., \& Bailey, L. R. (2008). The influence of college students' shopping orientations and gender differences on online information searches and purchase behaviours. International Journal of Consumer Studies, 32(2), 113-121.

Strang, R. (2013). Retail without boundaries. Supply Chain Management Review, 17(6), 32.

Taylor, P., \& Gao, G. (2014). Generation X: America's neglected "middle child” FACTANK. Pew Research Center. Retrieved from http://www.pewresearch.org/fact-tank/2014/06/05/generation-X-a

The Verde Group. (2011). Understanding the multi-channel shopper. Verde Group with the Jay H. Baker. Retailing Center at the Wharton School, University of Pennsylvania. Retrieved from http:/www.verdegroup.com/wp-content/uploads/2012/10/The-Multi-Channel-Shopper-Market-St udy.pdf

Trocchia, P. J., Saine, R. Q., \& Luckett, M. G. (2015). I've wanted a BMW Since I was a kid: An exploratory analysis of the aspirational brand. Journal of Applied Business Research, 31(1), 331-343.

Valentine, D. B., \& Powers, T. L. (2013). Online product search and purchase behavior of Generation Y. Atlantic Marketing Journal, 2(1), 6.

Vroman, K. G., Arthanat, S., \& Lysack, C. (2015). Who over 65 is online? Older adults' dispositions toward information communication technology. Computers in Human Behavior, 43, 156-166.

Williams, K. C., \& Page, R. A. (2011). Marketing to the generations. Journal of Behavioral Studies in Business, 3(1), 37-53. 